the potential impact of fortified foods on consumption patterns. It's an "important area that needs to be addressed," he said, adding that educational measures would help consumers make healthy choices.

Tarasuk, though, questions whether education will have any impact when it comes to discretionary fortification.

"People have an understanding of nutrients as good for them," she says. "We can't expect people to know whether or not they need more niacin in their diet, or what their riboflavin status is, or what their pantothenic acid status is. We can't expect an individual going to the store to know those things. Somebody shouldn't need a $\mathrm{PhD}$ to go grocery shopping."

Lynda Corby, registered dietitian and director of public affairs for the Dietitians of Canada, says the problem is compounded by the fact that nutrition facts panels do not indicate whether the source of the nutrients is natural or added. That makes it difficult for consumers to decide whether it is a healthier product, she says.
Corby is also concerned that Health Canada's proposed Codex amendment does not clearly specify which types of foods could be fortified. The Dietitians of Canada, she says, "would certainly want to see some very strict parameters put around the kinds of foods that would be considered."

As proposed, Health Canada's Codex amendment states that "consideration could also be given to the question of whether there is a need for principles regarding the prohibition of voluntary fortification of certain types of foods and if so, which ones."

That basically leaves the door wide open for all foods, but Thomas states that Health Canada is re-evaluating their Codex proposal to determine if some foods should be exempt from discretionary fortification.

Tarasuk wonders if it is even possible to develop a set of conditional criteria for desirable and undesirable foods or nutrients when dietary intakes, choices and needs vary by food consumption patterns across countries.
"The idea that there's a one-size-fits-all for these answers globally I think is crazy," she says.

An array of public health advocacy groups have spoken out against discretionary fortification, including the Dietitians of Canada, the Canadian Diabetes Association, the Heart and Stroke Foundation of Canada, the Canadian Paediatric Society, the Coalition québécoise sur la problématique du poids, the Canadian Public Health Association, the Ontario Public Health Association and the Ontario Society of Nutrition Professionals in Public Health. That prompts Tarasuk to wonder about Health Canada's motivations.

"If there aren't health advocates demanding more niacin in potato chips or more B vitamins in fruit-flavoured water, who's advocating for it?" she asks. "If it isn't health practitioners, it's got to be manufacturers and why would Health Canada then make that a priority?" Yoni Freedhoff MD, Ottawa, Ont.

DOI:10.1503/cmaj.109-3185

\title{
United States scrambles for secure, safe isotope supply
}

Previously published at www.cmaj.ca

$\mathrm{B}$ uffeted by geopolitics from afar and the needs of patients at home, the United States is moving on two fronts to secure the supply of isotopes vital in medical imaging but dangerous in the wrong hands.

No longer able to depend on the traditional Canadian and Dutch suppliers, Washington is accelerating efforts to jump-start domestic production of the molybdenum- 99 isotope. At the same time, policy-makers want to wean the world off of the weapons-grade uranium used to make isotopes and achieve conversion to low-enriched uranium, a promising but unproven path to solving the global isotope shortage.

This tricky juggling act is incorporated in legislation before the US Congress. It was spurred by the indefinite loss of supplies from Canada's National Research Universal (NRU) reactor in Chalk River, Ontario, and

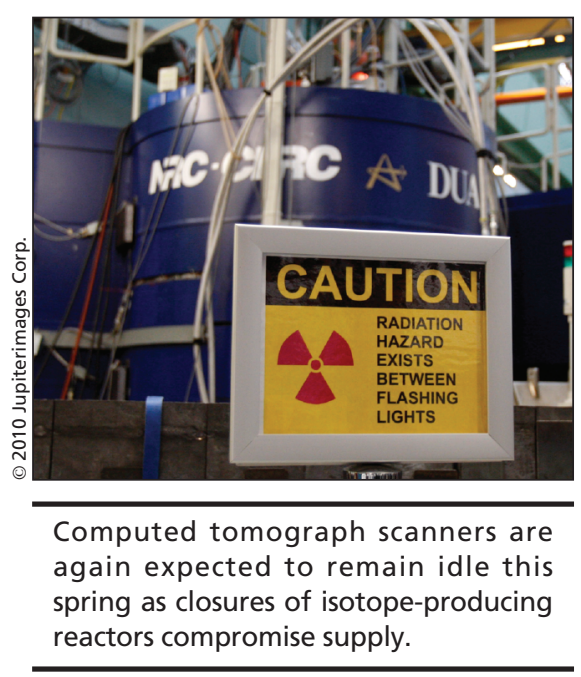

extended interruptions from the other major source, in the Netherlands.

The House of Representatives passed a bill in November 2009, with overwhelming support from both parties, which would release US\$163 million over five years to find means of producing the isotope from lowenriched uranium.

The legislation also would ban the export of highly enriched uranium in seven to 11 years, putting pressure on foreign producers to stop using materials that can be diverted to nuclear weapons development. A similar bill cleared a Senate committee in January, then stalled as a senator sought further study.

This, as supplies have plunged over the past year to $20 \%-30 \%$ of needed levels, leaving caregivers scrambling to keep up in the diagnosis and treatment of cancer, heart disease and other medical conditions. The US found short-term alternatives when the Chalk River reactor was shut down but now the High Flux Reactor in Petter, the Netherlands, is closed for repairs until August.

"It's not a very good situation," says Dr. Michael M. Graham, president of the US Society of Nuclear Medicine. Society 
members are expecting they'll soon face soon face widespread disruptions of imaging studies. The US consumes half the world's supply of molybdenum-99 - from which the radioistotope technetium-99m is fabricated for use in imaging - of which some $60 \%$ has traditionally been supplied by the NRU.

President Barack Obama's administration isn't waiting for the legislation to grind through Congress. The Energy Department recently announced seed money for two pilot projects aimed at coaxing elusive molybdenum- 99 from existing commercial reactors and a lowenrichment mini-reactor. Still, a new and reliable supply chain is years off.

The US National Academy of Sciences provided an impetus to move from bomb-grade uranium last year in a report that concluded low-enriched uranium not suitable for weapons - could technically be used in the production of adequate supplies of medical isotopes over time (http://dels.nas.edu/dels/viewreport .cgi?id=5559). Argentina and Australia are already producing limited quantities of molybdenum-99 isotopes using lowenrichment uranium.

If the technology is feasible, though, it's still formative. "As new reactors get designed and begin to get built there's very definitely going to be an effort to shift to LEU [low-enriched uranium]," says Graham.

The search for stable, safe supplies is playing out as the US and Iran engage in diplomatic brinkmanship over Tehran's nuclear program. It's a standoff at the intersection of nuclear medicine and apocalyptic weaponry Iran insisting on its right to produce medical isotopes, the global community suspicious that it's a cover for development of nuclear weapons.

Iran declared this month that it has begun enriching uranium to $20 \%$ purity, up from $3.5 \%$, for the production of medical isotopes. From there, it's not an impossible leap to the purity required in a bomb. For the US, that's emblematic of the need to find a benign alternative to a tried-and-true material that saves lives but comes with a dark side, in a world going rogue. - Cal Woodward, Washington, DC

\section{More news at www.cmaj.ca}

Canada's electronic health records initiative stalled by federal funding freeze: The federal government's failure to release $\$ 500$ million in promised funding has slowed the next phase of the multibillion-dollar national effort to implement electronic health records, says Canada Health Infoway President Richard Alvarez. — Paul Christopher Webster, Toronto, Ont.

Fund proposed to pay for drugs with greater global impact: A Canadian economist is proposing that pharmaceutical innovators sell their products at cost and receive payments from a global fund based on demonstrated global health impact. - Lauren Vogel, Ottawa, Ont.

Medical services at the Olympics a monumental challenge: Organizing and providing health and medical services for the anticipated 5500 Olympians and officials, 1350 Paralympians, 10000 media representatives, 25000 volunteers, as well as untold tourists, visiting British Columbia for the 2010 Winter Olympics will be a monumental task. - Neda Amiri and Goldis Chami, Vancouver, BC

American health care reformers in search of a second wind: Due to setbacks in political fortunes and legislative prospects, the Democratic party in the United States has practically gone underground on the issue of health care reform. - Cal Woodward, Washington, DC

Rosy outlook for people with diabetes: Many researchers are exploring noninvasive means to monitor glucose levels, and one proposed alternative to drawing blood is to monitor glucose in tears. - Roger Collier, CMAJ

The future of eye tech: It may someday be possible to wear high-tech contact lenses capable of monitoring your glucose levels, displaying video and accessing the Internet. - Roger Collier, CMAJ

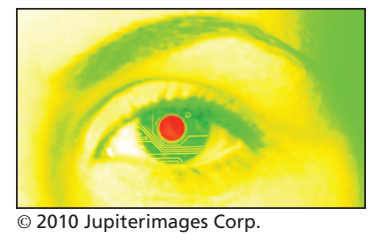

Safety institutes urge better bar-coding of drugs: Improved bar-coding of all drugs, and standardization of bar-coding, would significantly reduce medication errors and save lives, say the Institute of Safe Medication Practices Canada and the Canadian Patient Safety Institute. - Brittany Hinds, Ottawa, Ont.

Quebec stands firm on asbestos exports despite growing controversy: Quebec Premier Jean Charest is refusing to stop exporting chrysotile asbestos, despite a growing international outcry. — Laura Eggertson, Ottawa, Ont.

The challenges of quantifying quality: Statistics are clear indicators of performance in some professions, but not in medicine, which some doctors say is as much an art as it is a science. - Roger Collier, CMAJ

\section{Dispatches}

Haiti earthquake, a personal perspective: A Montréal, Quebec, physician says the resilience of Haiti's residents will carry them through, following the horrific earthquake that struck their nation. - Dan Leon Deckelbaum, Montréal, Que.

DOI:10.1503/cmaj.109-3188 